
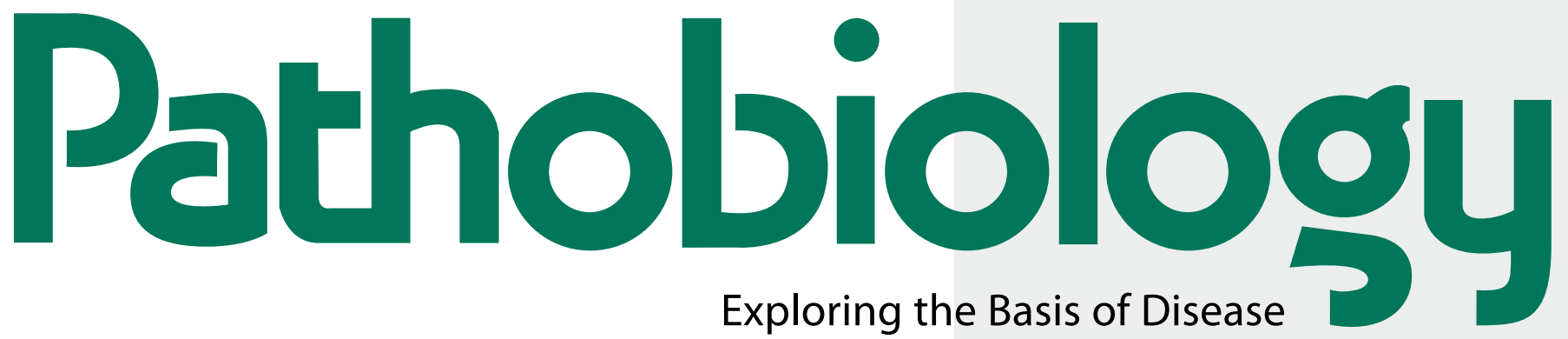

Exploring the Basis of Disease

\title{
Application of Novel Biomaterials in Clinical Surgery
}

Editor

Brigitte Vollmar, Rostock 


\title{
Transforming Vesalius
}

The medical revolution of the 16th century brought to life for the 21st century

\author{
ANDREAS VESALIUS
}

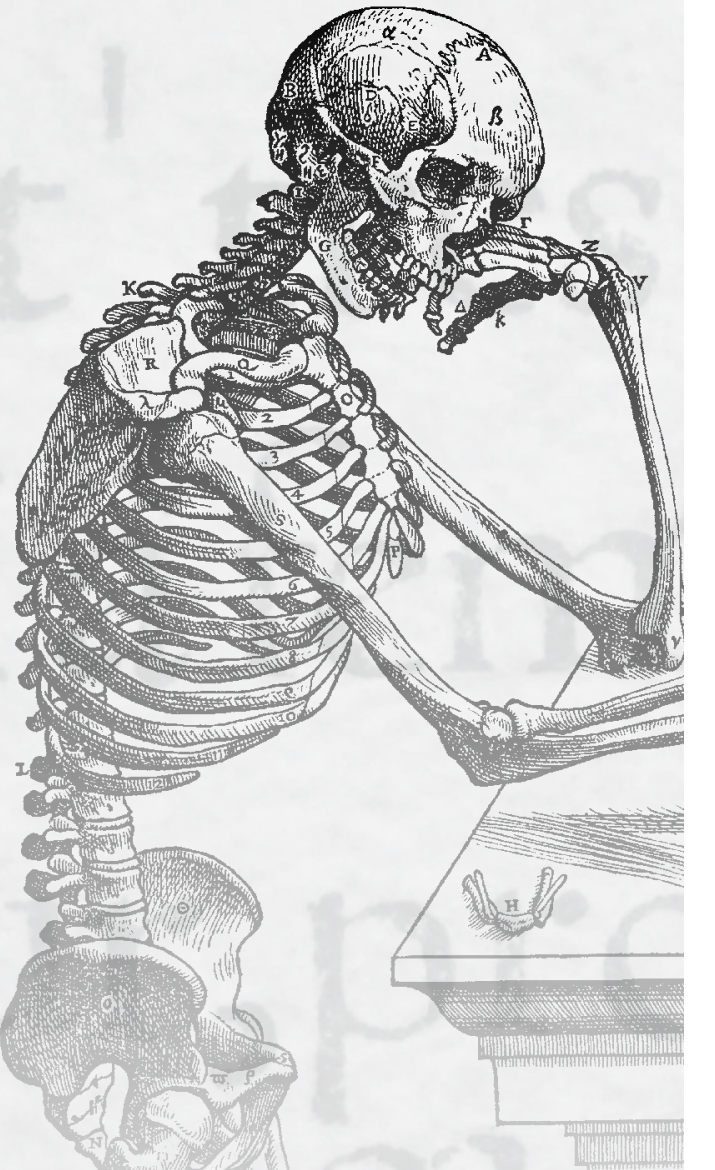

Vesalius, A.

The Fabric of the Human Body An Annotated Translation of the 1543 and 1555 Editions of "De Humani Corporis Fabrica", by D. H. Garrison and M. H. Hast

Approx. 1,400 pages in two books Hard cover with slip case

$12 \times 17^{\prime \prime} / 315 \times 435 \mathrm{~mm}$

Approx. $30 \mathrm{lbs} / 14 \mathrm{~kg}$

List price: CHF 1,500.- / EUR 1,250.- / USD 1,650.00

Pre-publication price: CHF 1,125.- / EUR 935.- / USD 1,235.00 Valid until end of September 2013 Postage and handling included VAT \& import taxes excluded EUR price for Germany, USD price for USA only ISBN 978-3-318-02246-9

\section{The Fabric of the Human Body}

An Annotated Translation of the 1543 and 1555 Editions of "De Humani Corporis Fabrica" by

\author{
DANIEL H. GARRISON \\ MALCOLM H. HAST
}

- Modern layout enables the 21st-century reader to understand the complexity and pioneering nature of this milestone in medical history without the need of knowing Latin

- Different colors allow easy identification of notes relevant to both the 1543 and the 1555 editions

- Added notes for a never published third edition

- Up-to-date design and high-resolution digital scans of the woodcuts

- Nomina Anatomica and Terminologia Anatomica for the first time included to provide Vesalius' descriptions with modern medical terminology

- Prefaces by the translators and introductions by medical historians Vivian Nutton and Nancy Siraisi

Special pre-publication offer until September 2013

www.vesalius-fabrica.com 


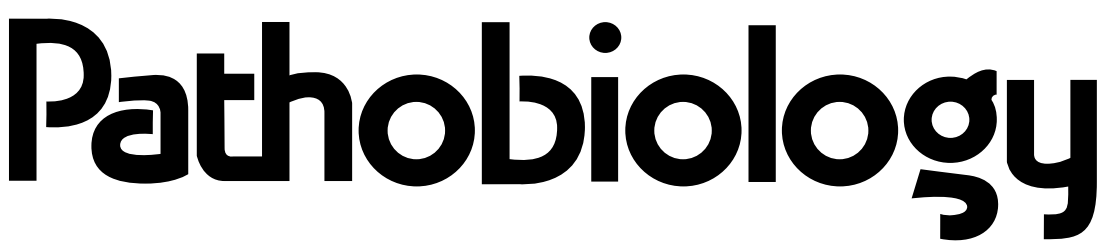

Founded 1938 as 'Schweizerische Zeitschrift für allgemeine Pathologie und Bakteriologie' by A. v. Albertini, A. Grumbach and H. Mooser, continued as 'Pathologia et Microbiologia' (1960-1975) and 'Experimental Cell Biology' (1976-1989); incorporating 'Pathology and Immunopathology Research', founded 1982 as ‘Survey and Synthesis of Pathology Research' by J.M. Cruse and R.E. Lewis, continued as 'Pathobiology', edited by J.M. Cruse and R.E. Lewis (1990-1998) Continued by Ch. Wittekind (1999-2004)

\section{Editor-in-Chief}

B. Borisch, Geneva

\section{Regional Editor: Far East}

W. Yasui, Hiroshima

\section{Editorial Board}

H. Denk, Graz

P.L. Fernandez, Barcelona

A. Horii, Sendai

C. Jackson, Sydney, N.S.W.

A. Janin, Paris

A. Katalinic, Lübeck

C.J. Kirkpatrick, Mainz

S. Kumar, Manchester

J.A. Kummer, Utrecht

H.-A. Lehr, Lausanne

A. Perren, Bern

S.A. Pileri, Bologna
S. Pinder, London

A. Porwit, Toronto, Ont.

M. Reymond, Herne

A. Shaaban, Leeds

P. Suat-Cheng, Kuala Lumpur

A. Tannapfel, Bochum

J. Van der Walt, London

M. Werner, Freiburg

H-K. Yang, Seoul

K. Zatloukal, Graz

W.L. Zhao, Shanghai
Printed in Switzerland on acid-free and non-aging paper (ISO 9706) by Reinhardt Druck, Basel
Appears bimonthly: 1 volume per year (6 issues) 


\section{Pathobiology}

\section{Aims and Scope}

Pathobiology offers a valuable forum for high quality original research into the pathophysiological and pathogenetic mechanisms underlying human disease. Aiming to serve as a bridge between basic biomedical research and clinical medicine, the journal welcomes articles from scientific areas such as pathology, oncology, anatomy, virology, internal medicine, surgery, cell and molecular biology, and immunology. Published bimonthly, the journal features original research papers, reviews, short communications and editorials. Papers highlighting the clinical relevance of pathological data are encouraged. A special section will be devoted to reports on methodological improvements, and in the 'International Forum' section current or controversial issues will be discussed by specialists in the field.

\section{Submission}

Manuscripts should be submitted using the online submission website at:

\section{www.karger.com/pat}

Should you experience any problems with your submission, please contact:

\section{Laetitia.Bourquin@unige.ch \\ Prof. Dr. Bettina Borisch \\ Centre Médical Universitaire \\ 1 , rue Michel-Servet \\ $\mathrm{CH}-1211$ Genève 4 (Switzerland)}

\section{Conditions}

Manuscripts must be written in English, and are all subject to peer review. Manuscripts are received with the explicit understanding that they are not submitted for simultaneous consideration by any other publication. Submission of an article for publication implies the transfer of the copyright from the author to the publisher upon acceptance. Accepted papers become the permanent property of 'Pathobiology' and may not be reproduced by any means, in whole or in part, without the written consent of the publisher. It is the author's responsibility to obtain permission to reproduce illustrations, tables, etc. from other publications. For papers that are accepted for publication, manuscript copies and illustrations will not be returned to the authors. For papers that are rejected, only the set of original figures will be returned.

\section{Arrangement}

Title page: The first page of each paper should indicate the title, the authors' names, the institute where the work was conducted, and a short title for use as running head.

Full address: The exact postal address of the corresponding author complete with postal code must be given at the bottom of the title page. Please also supply phone and fax numbers, as well as e-mail address.

Key words: Please supply 3-10 key words in English that reflect the content of the paper.

Abstract: Each paper needs an abstract of up to 200 words structured with subheadings as follows: Objective(s), Methods, Results, Conclusion(s).

Footnotes: Avoid footnotes. When essential, they are numbered consecutively and typed at the foot of the appropriate page.

Tables and illustrations: Tables and illustrations (both numbered in Arabic numerals) should be prepared on separate sheets. Tables require a heading and figures a legend, also prepared on a separate sheet. For the reproduction of illustrations, only good drawings and origina photographs can be accepted; negatives or photocopies cannot be used. Due to technical reasons, figures with a screen background should not be submitted. When possible, group several illustrations on one block for reproduction (max. size $180 \times 223 \mathrm{~mm}$ ) or provide crop marks. On the back of each illustration, indicate its number, the author's name, and 'top' with a soft pencil. Electronically submitted b/w half-tone and color illustrations must have a final resolution of $300 \mathrm{dpi}$ after scaling, line drawings one of 800-1200 dpi.

Color illustrations

Online edition: Color illustrations are reproduced free of charge. In the print version, the illustrations are reproduced in black and white. Please avoid referring to the colors in the text and figure legends.

Print edition: Up to 6 color illustrations per page can be integrated within the text at CHF 800.- per page.

\section{References}

In the text identify references by Arabic numerals [in square brackets]. Material submitted for publication but not yet accepted should be noted as 'unpublished data' and not be included in the reference list. The list of references should include only those publications which are cited in the text. Do not alphabetize; number references in the order in which they are first mentioned in the text. The surnames of the authors followed by initials should be given. There should be no punctuation other than a comma to separate the authors. Preferably, please cite all authors. Abbreviate journal names according to the Index Medicus system. (Also see International Committee of Medical Journal Editors: Uniform requirements for manuscripts submitted to biomedical journals. N Engl J Med 1997;336:309-315.)

\section{Examples}

(a) Papers published in periodicals: Sun J, Koto H, Chung KF: Interaction of ozone and allergen challenges on bronchial responsiveness and inflammation in sensitised guinea pigs. Int Arch Allergy Immunol 1997;112:191195.

\section{(b) Papers published only with DOI numbers:}

Theoharides TC, Boucher W, Spear K: Serum interleukin-6 reflects disease severity and osteoporosis in mastocytosis patients. Int Arch Allergy Immunol DOI: $10.1159 / 000063858$

(c) Monographs: Matthews DE, Farewell VT: Using and Understanding Medical Statistics, ed 3, revised. Basel, Karger, 1996.

(d) Edited books: Parren PWHI, Burton DR: Antibodies against HIV-1 from phage display libraries: Mapping of an immune response and progress towards antiviral immunotherapy; in Capra JD (ed): Antibody Engineering. Chem Immunol. Basel, Karger, 1997, vol 65, pp 18-56.

Reference Management Software: Use of EndNote is recommended for easy management and formatting of citations and reference lists.

\section{Digital Object Identifier (DOI)}

S. Karger Publishers supports DOIs as unique identifiers for articles. A DOI number will be printed on the title page of each article. DOIs can be useful in the future for identifying and citing articles published online without volume or issue information. More information can be found at www.doi.org.

\section{Supplementary Material}

Supplementary material is restricted to additional data that are not necessary for the scientific integrity and conclusions of the paper. Please note that all supplementary files will undergo editorial review and should be submitted together with the original manuscript. The Editors reserve the right to limit the scope and length of the supplementary material. Supplementary material must meet production quality standards for Web publication without the need for any modification or editing. In general, supplementary files should not exceed $10 \mathrm{MB}$ in size. All figures and tables should have titles and legends and all files should be supplied separately and named clearly. Acceptable files and formats are: Word or PDF files, Excel spreadsheets (only if the data cannot be converted properly to a PDF file), and video files (.mov, .avi, .mpeg).

\section{Author's Choice ${ }^{\mathrm{TM}}$}

Karger's Author's Choice ${ }^{\mathrm{TM}}$ service broadens the reach of your article and gives all users worldwide free and full access for reading, downloading and printing at www. Karger.com. The option is available for a one-time fee of CHF 3000.-, which is a permissible cost in grant allocation. More information can be found at www.karger. com/authors_choice.

\section{NIH-Funded Research}

The U.S. National Institutes of Health (NIH) mandates under the NIH Public Access Policy that final, peer-reviewed manuscripts appear in its digital database within 12 months of the official publication date. As a service to authors, Karger submits the final version of your article on your behalf to PubMed Central. For those selecting our premium Author's Choice ${ }^{\mathrm{TM}}$ service, we will send your article immediately upon publishing, accelerating the accessibility of your work without the usual embargo. More details on NIH's Public Access Policy is available at http://publicaccess.nih.gov/policy.htm

\section{Self-Archiving}

Karger permits authors to archive their pre-prints (i.e. pre-refereeing) or post-prints (i.e. final draft post-refereeing) on their personal or institution's servers, provided the following conditions are met: Articles may not be used for commercial purposes, must be linked to the publisher's version, and must acknowledge the publisher's copyright. Authors selecting Karger's Author's Choice ${ }^{\mathrm{TM}}$ feature, however, are also permitted to archive the final, published version of their article, which includes copyediting and design improvements as well as citation links.

\section{Page Charges}

There is no page charge for papers of 7 or fewer printed pages (including tables, illustrations and references). Each additional complete or partial page is charged to the author at CHF 325.-. 3 manuscript pages (including tables, illustrations and references) are equal to approximately one printed page.

\section{Electronic Proofs}

Unless indicated otherwise, proofs will be e-mailed to the corresponding author.

\section{Reprints}

Order forms and a price list are sent with the proofs. Orders submitted after the issue is printed are subject to considerably higher prices.

\section{KARGER}

E-Mail karger@karger.com www.karger.com
(C) 2013 S. Karger AG, Basel 


\section{Pathobiology}

ISSN Print Edition: 1015-2008

ISSN Online Edition: 1423-0291

Journal Homepage: www.karger.com/pat

Publication Data: 'Pathobiology' is published 6 times a year. Volume 80 with 6 issues appears in 2013.

Copyright: (c) 2013 S. Karger AG, Basel (Switzerland). All rights reserved. No part of this publication may be translated into other languages, reproduced or utilized in any form or by any means, electronic or mechanical, including photocopying, recording, microcopying, or by any information storage and retrieval system, without permission in writing from the publisher or, in the case of photocopying, direct payment of a specified fee to the Copyright Clearance Center.

Disclaimer: The statements, opinions and data contained in this publication are solely those of the individual authors and contributors and not of the publisher and the editor(s). The appearance of advertisements in the journal is not a warranty, endorsement, or approval of the products or services advertised or of their effectiveness, quality or safety. The publisher and the editor(s) disclaim responsibility for any injury to persons or property resulting from any ideas, methods, instructions or products referred to in the content or advertisements.
Subscription Rates: Subscriptions run for a full calendar year. Prices are given per year. Personal subscription:

Print or Online

CHF 495.-

EUR 399.-

USD 490.00

Print+Online combined CHF 543.-

EUR 437.-

USD 538.00

postage and handling (added to print and print+online)

CHF 43.20 Europe, CHF 62.40 Overseas

EUR 33.60

USD 57.60

Institutional subscription

Print or Online

Print+Online combined

CHF 1978.

EUR 1595.-

CHF 2176.-

USD 1958.00

USD 2154.00

postage and handling (added to print and print+online)

CHF 54.- Europe, CHF 78.- Overseas

EUR 42.-

USD 72.00

Airmail surcharge: CHF 52.50 / USD 49.50

Discount subscription prices: Members of the AAI.
Back Volumes and Single Issues: Information on availability and prices of single print issues and print or electronic back volumes can be obtained from Customer Service at service@karger.ch.

Bibliographic Indices: This journal is regularly listed in bibliographic services, including Current Contents ${ }^{\circledR}$ and PubMed/MEDLINE.

Photocopying: This journal has been registered with the Copyright Clearance Center (CCC), as indicated by the code appearing on the first page of each article. For readers in the US, this code signals consent for copying of articles for personal or internal use, or for the personal or internal use of specific clients, provided that the stated fee is paid per copy directly to

Copyright Clearance Center Inc.

222 Rosewood Drive

Danvers, MA 01923 (USA)

A copy of the first page of the article must accompany payment. Consent does not extend to copying for general distribution, for promotion, for creating new works, or for resale. In these cases, specific written permission must be obtained from the copyright owner,

S. Karger AG, P.O. Box

CH-4009 Basel (Switzerland).
Subscription Orders:

Orders can be placed at agencies, bookstores, directly with the Publisher

Medical and Scientific Publishers

Allschwilerstrasse 10

CH-4009 Basel

Switzerland

$\mathrm{t}:+41613061111$

e: karger@karger.com

w: www.karger.com

(for courier services only:

Allschwilerstrasse 10

CH-4055 Basel)

\section{S. Karger AG}

f: +41613061234

\begin{tabular}{|c|c|}
\hline $\begin{array}{l}\text { or further Karger offices } \\
\text { or representatives: }\end{array}$ & $\begin{array}{l}\text { USA } \\
\text { S. Karger Publishers, Inc. } \\
26 \text { West Avon Road }\end{array}$ \\
\hline Germany & P.O. Box 529 \\
\hline S. Karger GmbH & Unionville, CT 06085 \\
\hline Postfach & USA \\
\hline 79095 Freiburg & Toll free: +18008285479 \\
\hline Deutschland & $\mathrm{t}: \quad+18606757834$ \\
\hline (Hausadresse: Wilhelmstrasse 20A, & f: +18606757302 \\
\hline $\begin{array}{l}\text { 79098 Freiburg) } \\
\text { t: } \quad+49761452070\end{array}$ & e: karger@snet.net \\
\hline $\mathrm{f}: \quad+497614520714$ & France \\
\hline e: information@karger.de & Librairie Médi-Sciences Sarl \\
\hline w: www.karger.de & $\begin{array}{l}\text { 36, bd de Latour-Maubourg } \\
75007 \text { Paris }\end{array}$ \\
\hline Japan & France \\
\hline Karger Japan, Inc. & $\mathrm{t}:+33(0) 145514258$ \\
\hline Shiba Daimon Asahi Bldg. 2F & $\mathrm{f:}+33(0) 145560780$ \\
\hline 1-2-23 Shiba Daimon & e: librairie@medi-sciences.fr \\
\hline Minato-ku & w: www.medi-sciences.fr \\
\hline Tokyo 105-0012 & \\
\hline Japan & \\
\hline t: +81364356242 & \\
\hline$f:+81364356244$ & \\
\hline e: publisher@karger. & \\
\hline w: www.karger.j & \\
\hline
\end{tabular}

Change of Address:

Both old and new address should be sent

to the subscription source.

\section{KARGER}

E-Mail karger@karger.com www.karger.com
(C) 2013 S. Karger AG, Basel

The Journal Home Page is available at: www.karger.com/pat
South East Asia, China and Taiwan Karger Regional Office (Malaysia) CEO Suite Kuala Lumpur Quill 7, 27th Floor

Jalan Stesen Sentral 5

KL Sentral

Kuala Lumpur 50470

Malaysia

$\mathrm{t}:+60327766803$

f: +60327766999

e: service@karger.cn; r.chew@karger.cn

Karger China

10th Floor, Twin Towers (East)

B12 Jianguomenwai Avenue

Beijing 100022

China

t: +861051235033

f: +861051235122

e: service@karger.cn; r.chew@karger.cn

w: www.karger.cn

India, Bangladesh, Sri Lanka

Medscience India

Plot No. 17, Yusuf Sarai Market

B.L. Glass Building, 2nd Floor

Sri Aurobindo Marg

New Delhi 110016

India

t: +911146029633

f: +911146029634

c: +919891052128

e: medsci.india@gmail.com 


\section{Journal for regeneration biology, including cell and developmental biology, stem cell biology, tissue engineering and in vitro systems}

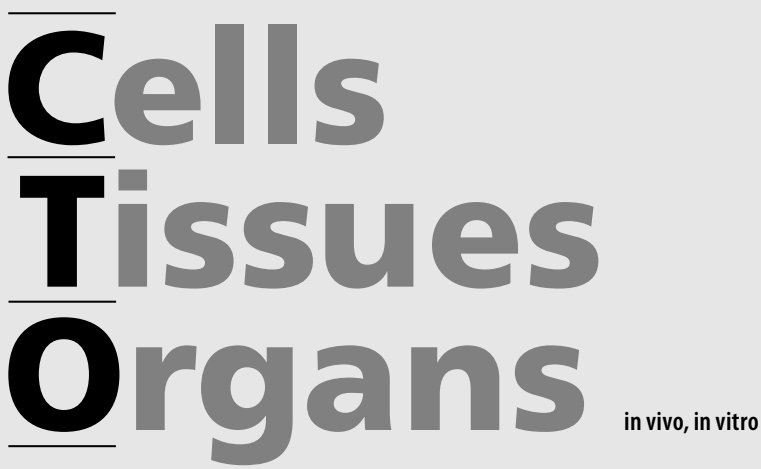

$\begin{array}{lll}\begin{array}{l}\text { Editors-in-Chief } \\ \text { H.-W. Denker, Essen }\end{array} & \text { Tumor Cell Plasticity } & \text { Neurosciences } \\ \text { A.W. English, Atlanta, Ga. } & \text { E. Thompson, Melbourne, Vic. } & \begin{array}{l}\text { R. Bellamkonda, Atlanta, Ga. } \\ \text { M. Frotscher, Freiburg i.Br. }\end{array} \\ & \text { Stem Cells and Tissue Engineering } & \text { W.L. Neuhuber, Erlangen } \\ \text { Associate Editors } & \text { S.F Badylak, Pittsburg, Pa. } & \text { M. Shoichet, Toronto, Ont. } \\ \begin{array}{l}\text { Developmental Biology } \\ \text { D. Newgreen, Melbourne, Vic. }\end{array} & \text { L.E. Niklason, Kew Haven, Conn. } & \text { Functional Anatomy and Biomechanics } \\ \text { C. Viebahn, Göttingen } & \text { A. Ratcliffe, San Diego, Calif. } & \text { L.M. Gallo, Zurich } \\ & \text { A.M. Wobus, Gatersleben } & \text { F. Eckstein, Salzburg }\end{array}$

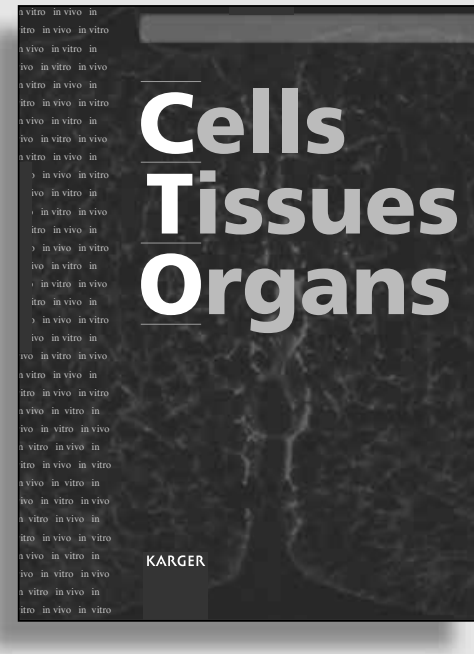

More information at

\section{www.karger.com/cto}

- Pay-per-View and Subscriber Access to Full Text

- Full Table of Contents

- Full Editorial Board

- Free Abstracts and Selected Articles

- Online Sample Issue

- Submission/Guidelines for Authors

- Subscription Details

- Free Alert Service

- Online Library Recommendation

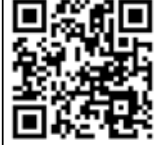

Cells Tissues Organs 2013: Volumes 197, 198 6 issues per volume Language: English ISSN 1422-6405 (print) ISSN 1422-6421 (online)

Listed in bibliographic services, including Current Contents $\%$ /Life Sciences, MEDLINE, Biological Abstracts, EMBASE/Excerpta Medica

\section{Selected contributions}

- Characterization of the Natural History of Extracellular Matrix Production in Tissue-Engineered Vascular Grafts during Neovessel Formation: Naito, Y.; Williams-Fritze, M.; Duncan, D.R.; Church, S.N.; Hibino, N.; Madri, J.A.; Humphrey, J.D.; Shinoka, T.; Breuer, C.K. (New Haven, Conn.)

- Tributyltin Alters Osteocalcin, Matrix Metalloproteinase 20 and Dentin Sialophosphoprotein Gene Expression in Mineralizing Mouse Embryonic Tooth in vitro: Salmela, E.; Alaluusua, S.; Sahlberg, C.; Lukinmaa, P.-L. (Helsinki)

-WT1 and Pax2 Re-Expression Is Required for Epithelial-Mesenchymal Transition in 5/6 Nephrectomized Rats and Cultured Kidney Tubular Epithelial Cells:

Huang, B.; Pi, L.; Chen, C. (Guangzhou); Yuan, F. (Dongguan); Zhou, Q.; Teng, J.; Jiang, T. (Guangzhou)

- Neurotrophin-3 Gene-Modified Schwann Cells Promote TrkC Gene-Modified Mesenchymal Stem Cells to Differentiate into Neuron-Like Cells in Poly (Lactic-Acid-C0-Glycolic Acid) Multiple-Channel Conduit: Zhang, Y.; He, L. (Guangzhou); Xing, B. (Dallas, Tex.); Zeng, X.; Zeng, C.; Zhang, W.; Quan, D.; Zeng, Y. (Guangzhou)

- Self-Organization Phenomena in Embryonic Stem Cell-Derived Embryoid Bodies: Axis Formation and Breaking of Symmetry during Cardiomyogenesis: Fuchs, C.; Scheinast, M.; Pasteiner, W.; Lagger, S.; Hofner, M.; Hoellrigl, A.; Schultheis, M.; Weitzer, G. (Vienna)

- BMP-2 and TGFß2 Shared Pathways Regulate Endocardial Cell Transformation: Townsend, T.A.; Robinson, J.Y.; Deig, C.R.; Hill, C.R.; Misfeldt, A. (Nashville, Tenn.); Blobe, G.C. (Durham, N.C.); Barnett, J.V. (Nashville, Tenn.)

- Engineered Vascular Tissue Fabricated from Aggregated Smooth Muscle Cells: Gwyther, T.A.; Hu, J.Z.; Christakis, A.G.; Skorinko, J.K.; Shaw, S.M.; Billiar, K.L.; Rolle, M.W. (Worcester, Mass.)
Cells Tissues Organs aims at bridging the gap between cell biology and developmental biology and the emerging fields of regenerative medicine (stem cell biology, tissue engineering, artificial organs, in vitro systems and transplantation biology). (TO offers a rapid and fair peer-review and exquisite reproduction quality. Special topic issues, entire issues of the journal devoted to a single research topic within the range of interests of the journal, are published at irregular intervals. 


\section{Contents}

See the journal website for contents

KARGER Basel $\bullet$ Freiburg $\cdot$ Paris $\bullet$ London $\bullet$ New York $\cdot$ New Delhi $•$ Bangkok Beijing $\cdot$ Tokyo $\cdot$ Kuala Lumpur $\cdot$ Singapore $\bullet$ Sydney 


\section{Innovative coverage of recent advances in \\ basic and translational medical research}

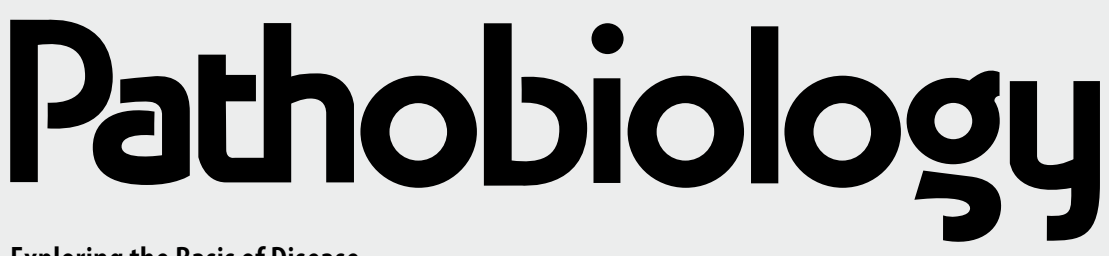

Exploring the Basis of Disease

\section{Editor-in-Chief}

B. Borisch, Geneva

Regional Editor: Far East

W. Yasui, Hiroshima

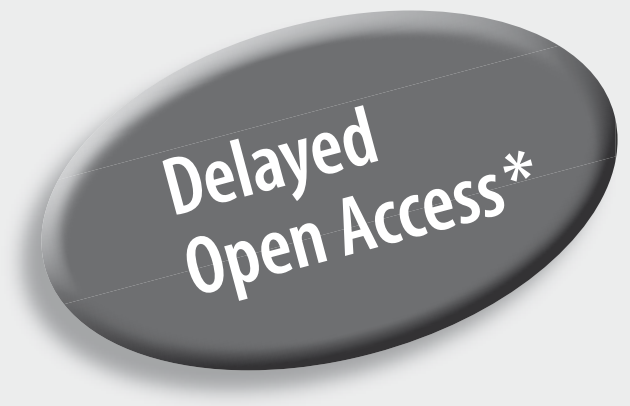

\section{Pathobiology}

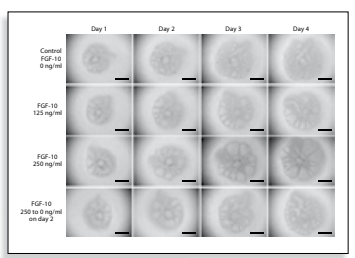

KARGER
More information at

\section{www.karger.com/pat}

- Pay-per-View and Subscriber Access to Full Text

- Full Table of Contents

- Full Editorial Board

- Free Abstracts and Selected Articles

- Online Sample Issue

- Submission/Guidelines for Authors

- Subscription Details

- Free Alert Service

- Online Library Recommendation

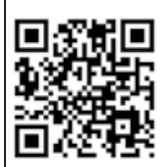

Pathobiology

2013: Volume 80

6 issues per volume

Language: English

ISSN 1015-2008 (print)

ISSN 1423-0291 (online)

\section{Selected contributions}

- Prolyl Hydroxylase Domain 2 Protein Is a Strong Prognostic Marker in Human Gastric Cancer: Kamphues, C.; Wittschieber, D.; Klauschen, F.; Kasajima, A.; Dietel, M.; Schmidt, S.-C.; Glanemann, M.; Bahra, M.; Neuhaus, P. (Berlin); Weichert, W.; Stenzinger, A. (Heidelberg)

- DNMT3B (C46359T) Polymorphisms and Immunoexpression of DNMT3b and DNMT1 Proteins in Oral Lichen Planus: Fonseca-Silva, T.; de Oliveira, M.V.M.; de Carvalho Fraga, C.A. (Montes Claros); Farias, L.C. (Montes Claros/Belo Horizonte); Gomes, É.P.P.; Barros, L.O. (Montes (laros); Roy, A. (London, Ont.); Gomez, R.S. (Belo Horizonte); De Paula, A.M.B.; Guimarães, A.L.S. (Montes Claros)

- Interferon (Alpha, Beta and Omega) Receptor 2 Is a Prognostic Biomarker for Lung Cancer: Tanaka, S.; Hattori, N.; Ishikawa, N.; Horimasu, Y.; Deguchi, N.; Takano, A.; Tomoda, Y.; Yoshioka, K.; Fujitaka, K.; Arihiro, K.; Okada, M. (Hiroshima); Yokoyama, A. (Nankoku City); Kohno, N. (Hiroshima)

- Road to Alzheimer's Disease: The Pathomechanism Underlying: Anand, R.; Kaushal, A.; Wani, W.Y.; Gill, K.D. (Chandigarh)

- Pathobiological Implications of MUC16/CA125 Expression in Intrahepatic Cholangiocarcinoma-Mass Forming Type: Higashi, M.; Yamada, N.; Yokoyama, S.; Kitamoto, S.; Tabata, K.; Koriyama, C. (Kagoshima); Batra, S.K. (Omaha, Nebr.); Yonezawa, S. (Kagoshima)

- Expression of MUC1, MUC2, MUC5AC and MUC5B in Mucinous Lesions of the Breast: Kim, D. (Suwon); Jung, W.-H.; Koo, J.S. (Seoul)

- Prognostic and Predictive Value of Cell Cycle Deregulation in Non-Small-Cell Lung Cancer: Sterlacci, W. (Feldkirch); Fiegl, M. (Innsbruck); Tzankov, A. (Basel)

- A Methyl-Deficient Diet Modifies Early B Cell Development: Kurogi, T.; Inoue, H.; Guo, Y.; Nobukiyo, A. (Hiroshima); Nohara, K. (Tsukuba); Kanno, M. (Hiroshima)
Pathobiology offers a valuable platform for the publication of high-quality original research into the mechanisms underlying human disease. Aiming to serve as a bridge between basic biomedical research and clinical medicine, the journal welcomes articles from scientific areas such as pathology, oncology, anatomy, virology, internal medicine, surgery, cell and molecular biology, and immunology. Published bimonthly, Pathobiology features original research papers and reviews on translational research. The journal offers the possibility to publish proceedings of meetings dedicated to one particular topic.

\footnotetext{
* One year after release of each issue's print version, all articles can be read and downloaded free of charge: www.karger.com/pat
} 


\section{Pathobiology}

\section{Application of Novel Biomaterials in Clinical Surgery}

This special issue of Pathobiology highlights novel biomaterials and their clinical use in surgery. As populations grow and expand, the need for replacement tissues and organs is constantly increasing and requires novel engineering strategies. Collective progress in the development of innovative materials and scaffolds capable of modulating the cellular responses required for tissue repair can only be achieved via collaborative interactions between investigators in the diverse Life Sciences disciplines.

Application of Novel Biomaterials in Clinical Surgery includes chapters on in vivo tissue engineering, the bioartificial pancreas, the repair of tendon and ligament injuries and resorbable osteosysnthesis materials in craniomaxilliofacieal surgery. Its main goal is to summarize the key messages of novel biomaterials and their application in clinical surgery.

The publication is of interest to academic surgeons of any field, as it highlights the integration of tissue-engineered materials into clinical practice. 